\title{
Using the courts to end corporal punishment - The international score card
}

\author{
Sonia Vohito \\ The Global Initiative to End All Corporal Punishment of Children
}

\begin{abstract}
SUMMARY
Corporal punishment of children breaches their rights to respect for human dignity and physical integrity and to equal protection under the law. There are a number of rulings and statements by national high-level courts concerning corporal punishment, its constitutionality and/or its non-compliance with international human rights treaties. The majority of these cases clearly condemn corporal punishment in one or more settings. In many cases, the rulings have been followed by law reform to ensure that national legislation prohibits corporal punishment. This article focuses on ten national high-level courts judgments and their impacts on achieving prohibition of corporal punishment of children in one or more settings. It highlights high-level court judgments clearly condemning corporal punishment of children (Bangladesh, Costa Rica, Fiji, India, Israel, Italy and Nepal), as well as judgments, which did not clearly condemn corporal punishment -(Canada, Kenya and Tonga) but had an impact on the legality of corporal punishment in the concerned countries. An analysis of the selected cases reveals that in addition to lobbying governments to achieve law reform, civil society organisations are increasingly promoting prohibition of corporal punishment by challenging the legality of corporal punishment in court. The article also finds judgments of high-level courts can trigger changes in the general perception of the protection and promotion of human rights. In some cases, judges have ruled against the legal defence of "reasonable chastisement" and clearly condemned the use of corporal punishment by parents and caregivers in private spheres. The article concludes on the need for considering strategic litigation as an alternative way of achieving prohibition of corporal punishment.
\end{abstract}

\section{Introduction}

Corporal punishment of children breaches their rights to respect for human dignity and physical integrity and to equal protection under the law. ${ }^{1}$ It is recognised by the Committee on the Rights of the Child ${ }^{2}$ and other treaty bodies, ${ }^{3}$ as well as by the UN Secretary General's Study on Violence against Children, ${ }^{4}$ as a highly significant issue, both for asserting children's status as rights holders and for the prevention of all

1 According to the Committee on the Rights of the Child, corporal punishment mostly involves hitting ("smacking", "slapping”, "spanking") children with the hand or with an implement (a whip, stick, belt, shoe, wooden spoon, or similar) but it can also involve, for example, kicking, shaking or throwing children, scratching, pinching, biting, pulling hair or boxing ears, forcing children to stay in uncomfortable positions, burning, scalding or forced ingestion. It also includes non-physical forms of

How to cite: Vohito 'Using the courts to end corporal punishment - The international score card' 2019 De Jure Law Journal 597-609

http://dx.doi.org/10.17159/2225-7160/2019/v52a34 
forms of violence. There is accelerating progress now across all regions, challenging this very common form of violence against children. To date, 54 states - including eight in Africa ${ }^{5}$ - have achieved prohibition in all settings, including the home. Typically, prohibition of corporal punishment is achieved through the adoption of clear and specific provisions that either amend existing laws or propose new legislations, or both. In countries where governments are refusing to introduce law reform or are actively opposing it, international and regional human rights mechanisms can also be used to "encourage" them to accept their obligations to realise children's rights. For instance, in Africa, pursuant to the African Union (AU) human rights monitoring mechanisms, complaints were made against African States, including Sudan, Senegal and Mauritania. In the case of judicial corporal punishment in Sudan, the African Commission on Human and Peoples' Rights held that there was no right for individuals, and particularly the government of a country to apply physical violence to individuals for offences. It requested that the government of Sudan amend the criminal law in question and abolish the penalty of lashes and compensate the victims (Curtis Francis Doebber $v$ Sudan, 236/2000). In the same vein, the African Committee on the Rights and Welfare of the child found that the beating of talibés (Quranic students) by marabouts (Muslim religious teachers) amounted to corporal punishment and violated their rights under article 16; Senegal was found in violation of the Charter as it had not adequately protected talibés children from all forms of violence. ${ }^{6}$

Similarly, in Europe, the European Committee of Social Rights has clearly condemned all corporal punishment of children. ${ }^{7}$ The 1996 Revised Social Charter requires states to take all appropriate and necessary measures to protect children against violence. ${ }^{8}$ In 2003 , collective complaints were submitted against Belgium, Greece, Ireland, Italy and Portugal, alleging that the states were in violation of the Charter

punishment that are cruel and degrading. See General Comment No. 8 (2006): The right of the child to protection from corporal punishment and other cruel or degrading forms of punishment (arts. 19; 28, para. 2, and 37, inter alia).

2 General Comment No. 8 (2006): The right of the child to protection from corporal punishment and other cruel or degrading forms of punishment (arts. 19; 28, para. 2, and 37, inter alia).

3 Also see the African Committee of Experts on the Rights and Welfare of the Child's General Comment No. 5 (2018): "State Party Obligations under the African Charter on the Rights and Welfare of the Child (Article 1) and systems strengthening for child protection" (para. 5.3.1, 5.3.2 and 5.3.3).

4 PS Pinheiro World Report on Violence against Children (2006).

5 The seven African states are Benin, Cabo Verde, Kenya, Republic of Congo, South Africa, South Sudan, Togo and Tunisia. For further information see www.endcorporalpunishment.org.

6 Decision of 14 April 2014 on communication No. 003/Com/001/ 2012, Centre for Human Rights and la Rencontre Africaine pour la Defense des Droits de l'Homme $v$ Senegal.

7 See World Organisation Against Torture (OMCT) v Portugal, complaint No. 34/2006, decision on the merits, para. 19-21.

8 See Article 17 of the Revised Social Charter. 
since corporal punishment was lawful. ${ }^{9}$ The European Committee of Social Rights found violations against Belgium, Greece and Ireland. ${ }^{10}$ In 2013, further complaints were submitted and declared admissible against Belgium, Cyprus, the Czech Republic, France, Ireland, Italy and Slovenia. ${ }^{11}$ The Committee found that the lack of clear prohibition in law of all corporal punishment of children violates the European Social Charter. The countries responded variably to the Committee's decision, including law reform to achieve full prohibition in the case of Cyprus and Ireland.

In addition to judgments and decisions made by international and regional human rights bodies, there have been a number of rulings and statements by national high-level courts $^{12}$ concerning corporal punishment, its constitutionality and/or its non-compliance with international human rights treaties. The majority of these cases clearly condemn corporal punishment in one or more settings, including in Costa Rica, Nepal, India and Israel; ${ }^{13}$ a minority of cases were less conclusive. In many cases, the rulings have been followed by law reform to ensure that national legislation prohibits corporal punishment. Overall, it appears that constitutional and legal provisions are increasingly used to challenge corporal punishment in all or some settings, in addition to using the international instruments, which the state has accepted.

In terms of advocacy, taking or threatening legal action can be part of a comprehensive strategy to promote law reform and ultimately achieve full prohibition. With the exception of judgments pronounced by Southern African high courts, ${ }^{14}$ this article will focus on ten worldwide national high-level courts judgments and their impacts on achieving

9 Resolution ResChS(2005)1, Collective complaint No. 19/2003 by the World Organisation against Torture (OMCT) against Italy, adopted by the Council of Ministers on 20 April 2005.

10 See World Organisation against Torture (OMCT) $v$ Belgium (Collective Complaint No. 21/2003, decision on the merits, 7 December 2004); World Organisation against Torture ('OMCT') v Greece case (Collective Complaint No. 17/2003, decision on the merits, 7 December 2004) and World Organisation against Torture (OMCT) v Ireland Complaint No 18/2003, decision on the merits of 7 December 2004.

11 Collective complaint No. 94/2013, Association for the Protection of All Children (APPROACH) Ltd $v$ Italy

12 For instance, see in South Africa, Freedom of Religion South Africa v Minister of Justice and Constitutional Development and Others (2019) CC, ZACC34; in Zambia, Banda v The People (2002) AHRLR 260 (ZaHC 1999) and in Israel, Criminal Appeal 4596/98 Plonit v A. G. 54(1) P. D.

13 See in Costa Rica: 2005-1062, Case No. 02-002448-0369-PE-(3); in Nepal: Supreme Court Order, Writ number 57 of the year 2061 (2005), Ale (CVICT) et al $v$ Government; in India: Parents Forum for Meaningful Education v Union of India and Another, 1 December 2000 and in Israel: Criminal Appeal 4596/ 98 Plonit v A. G. 54(1) P. D.

14 Southern African high-level judgments will be analysed in a separate article. 
prohibition of corporal punishment of children in one or more settings. ${ }^{15}$ It will notably feature the high-level court judgments clearly condemning corporal punishment of children, as well as judgments which did not clearly condemn corporal punishment but had an impact on the legality of corporal punishment in the concerned countries. The article concludes on the need for considering strategic litigation as an alternative way of achieving prohibition of corporal punishment.

\section{Judgments clearly condemning corporal punishment of children}

In addition to case laws in Southern Africa, there are seven national highlevel court judgments worldwide, which clearly condemn the use of corporal punishment against children. These include three cases in South Asia (Nepal, Bangladesh and India) and one respectively in Latin America (Costa Rica), the Middle East (Israel), Europe (Italy) and the Pacific (Fiji).

In Nepal, in 2005, following an application made by the Center for Victims of Torture concerning the constitutionality of section 7 of the Act relating to Children, 2048(1992), which provided for "minor beating" of children by family members and teachers, the Supreme Court ${ }^{16}$ ruled against corporal punishment inflicted by parents and teachers. Section 7 of the 1992 Children's Act provided that "any act by the mother, father, family member, guardian or teacher to scold the child or give him/her minor beating for the sake of his or her interests shall not be deemed to violate this Section". The Court noted the international human rights treaties to which Nepal is a party, stating "it is not proper and lawful to make laws in a manner contrary to the provisions of those treaties", and drew attention to countries which have prohibited physical punishment of children, adding "there seems no reason for Nepal not to take an initiative in the universal campaign against physical punishment or torture". It struck down the provision for "minor beating" and ordered Ministers to pursue measures to prevent physical punishment of children. The Supreme Court judgment played a significant role in Nepal's path toward full prohibition of corporal punishment of children. One year following the judgment, at the July 2006 meeting of the South Asia Forum, the Government made a commitment to enact prohibition in all settings, including the home. Nepal is member of the South Asia Initiative to End Violence against Children (SAIEVAC) an Apex Body of the South Asian Association for Regional Cooperation (SAARC), which aims to effectively implement measures to end all forms of violence against girls and boys including women in the sub region. ${ }^{17}$ In this regard, ending corporal punishment of children was considered as an

15 Southern Africa is the region recording the highest number of high-level court judgments on corporal punishment of children in Africa with eleven cases as at November 2019. This will be addressed in a forthcoming article.

16 Supreme Court Order, Writ number 57 of the year 2061 (2005), Ale (CVICT) et al $v$ Government. 
essential strategy for reducing and eliminating all other forms of violence against children in South Asia. In September 2018, Nepal became the 54th state worldwide - and the first state in South Asia - to prohibit corporal punishment of children when it adopted the Act Relating to Children 2018, which explicitly prohibits corporal punishment of children in all settings.

In India, a petition brought by the Parents' Forum for Meaningful Education and its President, Kusum Jain, challenged the legality of corporal punishment in schools as provided for in the Delhi School Education Rules 1973, arguing that it violated the Constitution. The Petition succeeded and the Court, in a judgment delivered on 1 December 2000 directed the State to ensure "that children are not subjected to corporal punishment in schools and they receive education in an environment of freedom and dignity, free from fear". The Court concluded that corporal punishment violated the Constitutional right to life (paras. 13-15 and 21) and held that it was "cruel to subject the child to physical violence in school in the name of discipline or education". It called on the State to ensure that corporal punishment of students is excluded from schools and that "the State and the schools are bound to recognise the right of the children not to be exposed to violence of any kind connected with education". Since the Delhi Supreme Court ruling, the Government has made a commitment to the prohibition of all corporal punishment, and during the Universal Periodic Review of India in 2012 accepted a recommendation to prohibit corporal punishment in all settings. The Right to Free and Compulsory Education Act 2009 explicitly prohibits physical punishment in some schools, and Rules under the Act provide for implementation of the prohibition through awareness raising, monitoring and complaints mechanisms. However, the Act applies only to children aged 6-14; it does not apply to unaided minority schools, Madrasas, Vedic Pathsalas and educational institutions primarily imparting religious instruction, nor does it apply in Jammu and Kashmir. Overall, prohibition is still to be achieved in the home, some alternative care settings, day care, some schools and as a sentence for crime in traditional justice systems.

In Bangladesh, a writ petition was filed as a public interest litigation in July 2010 by Bangladesh Legal Aid and Services Trust and Ain o Salish Kendra with the High Court in Dhaka, following several media reports of corporal punishment being meted out on children in government and non-government schools. The matter was referred to the Supreme Court $^{18}$ which found that corporal punishment in schools violated the Constitutional prohibition of torture and cruel, inhuman or degrading punishment or treatment. The Court then confirmed that although the Constitutional prohibition of "cruel, inhuman or degrading punishment

17 A regional initiative involving the following South Asian countries: Afghanistan, Bangladesh, Bhutan, India, Maldives, Nepal, Pakistan and Sri Lanka.

1813 January 2011, Writ Petition No. 5684 of 2010. 
or treatment" is stated in relation to trial and punishment, "it stands to reason that a child shall not be subjected to such punishment for behaviour in school which cannot be termed criminal offence". ${ }^{19}$ Reference was made to the harmful effects of corporal punishment, and the current law on corporal punishment in Bangladesh was considered. The Court went on to order that laws relating to disciplinary action against teachers be amended to identify the imposition of corporal punishment as misconduct, that all laws authorising corporal punishment be repealed, and that corporal punishment be prohibited in the home and workplaces.

With regard to achieving full prohibition, Bangladesh has already expressed its commitment to prohibiting all corporal punishment of children, including in the home, at a July 2006 meeting of the South Asia Forum, following the 2005 regional consultation of the UN Study on Violence against Children. Similarly, in 2009 and again in 2018 the Government accepted recommendations to prohibit corporal punishment made during the Universal Periodic Review of Bangladesh. However to date, the Supreme Court ruling against corporal punishment in schools has not led to confirmation in legislation, and prohibition is still to be achieved in the home, alternative care settings, day care, penal institutions and as a sentence for crime.

It should be noted that the Governments of Nepal, India and Bangladesh are all members of the SAIEVAC but their reactions to national judgments against corporal punishment of children differed. Only Nepal confirmed its court judgment by achieving full prohibition in law. India responded by adopting legislation that prohibits corporal punishment in some schools. However the SAIEVAC requires all member states to "have laws in place to ban corporal punishment in all settings including at home, schools, institutions, workplaces- ", by $2015^{20}$. This suggests that adherence to international or regional human rights mechanisms and initiatives may not always be the primary reason for Governments to engage in law reform to promote and protect human rights. Rather, Governments' political will may play a greater role in this process.

In Costa Rica, in 2005, the Criminal Court of Cassation of the Second Circuit Court of San Jose condemned corporal punishment inflicted by parents. ${ }^{21}$ It dismissed an appeal by a father convicted for punishing his daughter with a belt. The father's argument was that his actions were based on "a custom that has existed for over twenty years" and that he had used a soft belt that did not have a buckle. Based on the Family Code (article 143), the Court recognized the right and duty conferred under parental authority to, "in a moderate way, correct children". However, it argued that "... this can in no way be interpreted as a general

1913 January 2011, Writ Petition No. 5684 of 2010 (page 18).

20 http://www.techguthi.com/saievac/corporal-punishment/.

21 2005-1062, Case No. 02-002448-0369-PE-(3). 
authorization for parents or guardians of minors to hurt them without being punished for that action or simply to dispose of their lives as they please." Shortly after this judgment, Costa Rica reformed its legislation to prohibit corporal punishment of children by their parents and other adults. In June 2008, Parliament enacted the Law No. 8654 on the Rights of Children and Adolescents to Discipline Free from Corporal Punishment and Other Forms of Humiliating Treatment. This amended the Family Code by repealing the parental right to use moderate correction, it also explicitly prohibited corporal punishment in all settings by adding a new article to the Code on Children and Adolescents 1998 (article 24 bis).

The impact of the judiciary in prohibiting all corporal punishment of children has also proven to be noteworthy in Israel. A first judgment concerned corporal punishment in the school setting where the Supreme Court in $1994^{22}$ ruled against corporal punishment in both state and private schools. The Court found that corporal punishment could not constitute a "legitimate tool in the hands of teachers or other educators". The judgment was confirmed in legislation in 2000 when the Students' Rights Law 5761-2000 prohibited corporal punishment in schools (article 10). Secondly, concerning the home setting, in January 2000 Israel's Supreme Court ${ }^{23}$ effectively banned all parental corporal punishment, however light. The case concerned a woman convicted in the district court of assault and abuse against her two children. In appealing, she claimed that her actions were acceptable disciplinary measures. The court ruled that the legal defence was outdated and the "Israeli society had moved on from its reliance on English common law". It therefore held that parents should be forbidden to make use of corporal punishments or methods that demean and humiliate the child as an educational system. During the same year, the legal defence of "reasonable force" was repealed in law. It should also be noted that subsequent court rulings have confirmed the unacceptability and illegality of corporal punishment in childrearing. ${ }^{24}$

In Italy, in 1996, the Supreme Court of Cassation ${ }^{25}$ issued a decision on a case concerning a man who had been convicted of the crime of abuse of "the means of correction" under article 571 of the Penal Code and, in the appeals court, of ill-treatment under article 572 of the Code, for repeatedly physically punishing his daughter. The Court held that corporal punishment is not a legitimate method of correction and that to regard it as such was anachronistic and not in keeping with the development of Italian family law, the Constitutional provisions on human dignity and the Convention on the Rights of the Child. It also

22 The State of Israel $v$ Alagani.

23 Criminal Appeal 4596/98 Plonit v A. G. 54(1) P. D. p. 145.

24 For example Cr.C 40362/05 The State of Israel $v$ Onimaya Theodor (04.07.2006), Cr.A (Be'er-Sheva) 7161/02 The State of Israel v Z.Y. (12.2.2003), Cr.C (Ashkelon) 1414/06 The State of Israel $v$ Zur Yehoshua (9.9.2007).

25 Cambria, Cass, sez. VI, 18 Marzo 1996, Foro It II 1996, 407-414. 
stated that "the harmonious development of a child's personality, which ensures that he/she embraces the values of peace, tolerance and coexistence, cannot be achieved by using violent means which contradict these goals." However, this landmark judgment was not confirmed in legislation. The Italian law continues to provide for a right of correction ("jus corrigenda") in the home and all other settings where adults have parental authority. ${ }^{26}$

Finally, in Fiji, a High Court judgment condemned school and judicial corporal punishment in 2002. In the case of Naushad Ali $v$ State, ${ }^{27}$ concerning an appeal against a judicial sentence of six strokes of corporal punishment, the High Court stated that "punishment and treatment of persons by state institutions that may have been condoned in the past may be offensive for the present". The Court therefore ruled against both corporal punishment in schools and the sentence of six strokes. Following the 2002 judgment, Fiji has reformed its laws to prohibit corporal punishment in the penal system. ${ }^{28}$ It adopted Guidelines ${ }^{29}$ that banned corporal punishment in schools and has expressed a commitment to reform its laws to prohibit corporal punishment in all settings, including the home. The Fiji High Court was partially conclusive since judicial corporal punishment was prohibited, however corporal punishment is still to be achieved in the home, alternative care settings and day care. There are Guidelines banning corporal punishment in schools but they have not been confirmed in legislation.

As noted above, not all judgments clearly condemning corporal punishment have been confirmed in legislation. Among the seven concerned countries, only two (Nepal and Israel) have prohibited corporal punishment of children in all settings, including in the home. Israel's example is remarkable in the sense that the judgment that ruled against the legal defence was immediately followed by the enactment of a law prohibiting corporal punishment in the home. Moreover subsequent judgments confirmed prohibition in all settings. In this instance, a clear link can be established between the court decisions and law reform processes to achieve prohibition. This was also made possible by the fact that the concerned judgments specifically condemn the use of corporal punishment.

By contrast, there are high-level judgments that do not specifically condemn the use of corporal punishment, which may still have an impact on the legality of corporal punishment of children in countries. It is therefore important to shed light on these case laws and analyse their role in ending legalized violence against children.

26 Article 571 of the Criminal Code 1975.

27 Criminal Appeal No. HAA 0083 of 2001.

28 Prisons and Corrections Act 2006 (article 38).

29 Guidelines of the Permanent Secretary, Education Gazette Vol. III, 2003. 


\section{Judgments that do not clearly condemn corporal punishment}

In Tonga, in the case of Fangupo $v$ Rex; Fa'aoa $v$ Rex, ${ }^{30}$ in 2010 , the Appeal Court overturned sentences of judicial whipping that had been imposed on two 17 year olds, stating that in light of international convention and decisions of the court "it might be argued" that the provisions for whipping are now unconstitutional. In the same year, a private members bill to abolish judicial whipping was under discussion, but this was not enacted. Prohibition is still to be achieved in the home, alternative care settings, day care, as a sentence for crime and possibly in some penal institutions. In the case of Tonga, the Appeal Court judgment has clearly trigged a law reform process to prohibit judicial corporal punishment. However, this was not followed by the adoption of a prohibiting law. The argument as to whether a more explicit judgment would have led to the enactment of a new law is debatable since a law reform process did take place soon as after the judgment was pronounced.

In 2004, in the case of Canadian Foundation for Children, Youth and the Law $v$ Canada (Attorney General), ${ }^{31}$ the Supreme Court examined the constitutionality of section 43 of the Criminal Code, according to which the use of "reasonable force" against children is not a criminal offence. The court's ruling was peculiar in the sense that it condemned all corporal punishment in schools, but upheld the legality of corporal punishment of children in the home, with certain limitations. The Court found that section 43 justifies only "minor corrective force of a transitory and trifling nature" and that it rules out corporal punishment of children under the age of two years or over the age of 12 years, as well as degrading, inhuman or harmful conduct, discipline using objects such as rulers or belts and blows or slaps to the head. It therefore failed to find that section 43 of the Criminal Code was unconstitutional under the Canadian Charter of Human Rights. Following the ruling, prohibition of corporal punishment in schools has been confirmed in education law in Saskatchewan (2005) and Ontario (2009), not all states have achieved the necessary law reform. In sum, prohibition is still to be achieved in the home, some alternative care settings, day care and some schools.

In Kenya, while not categorically ruling out all corporal punishment, a High Court judgment confirmed that parental "discipline" could constitute cruel, inhuman and degrading treatment and could be a matter for the courts. The case of Isaac Mwangi Wachira $v$ Republic High Court of Kenya (Nakuru) ${ }^{32}$ in 2004, concerned a man convicted of

30 Fangupo v Rex; Fa'aoa v Rex [2010] TOCA 17; AC 34 of 2009; AC 36 of 2009 (14 2010).

31 Canadian Foundation for Children, Youth and the Law v Canada (Attorney General), [2004] 1 S.C.R. 76, 2004 SCC 4.

32 Isaac Mwangi Wachira $v$ Republic High Court of Kenya (Nakura), Criminal Application No 185 of 2004 (Unreported). 
subjecting his 3-year-old daughter to torture under the Children's Act. The defendant made an appeal against the length of his sentence of imprisonment. The High Court rejected the appellant's argument that the fact he was a parent disciplining his child was a mitigating factor. It should be noted that the case concerned the severe and sustained beating and pinching of a young child and the judgment addresses only the level of punishment, which would fall outside what many people would call "reasonable". However, it can be said that this was a landmark decision because it affirms the right of children under the new Act to be protected from torture and cruel, inhuman and degrading treatment and asserts that a parent's behaviour under the guise of discipline can constitute such treatment (traditionally seen to be committed by the state and not private individuals). It also confirmed the power of the courts to examine the status of corporal punishment in the home. It may be argued that the Isaac Mwangi Wachira $v$ Republic High Court of Kenya (Nakuru) contributed to building the momentum toward prohibition of all corporal punishment of children in Kenya. ${ }^{33}$ Indeed, in 2010, Kenya adopted a new Constitution which prohibits corporal punishment of children in all settings. ${ }^{34}$

\section{Strategic litigation and ending corporal punishment of children}

While it is true that prohibition of corporal punishment is mostly achieved through law or constitutional reform process, challenging corporal punishment in all or some settings before the courts can be considered. Legal action would "force" governments that are refusing to introduce law reform or are actively opposing it, to accept their obligations to realise children's rights. The examples of Nepal and Costa Rica and Israel establish a direct link between strategic litigation and prohibition of corporal punishment. While Israel immediately adopted a prohibiting law, in Nepal and Costa Rica the high-level judgments undeniably built momentum towards prohibition and prohibiting laws were ultimately enacted. More importantly, it should be pointed out that in common law countries, based on the national legal system, a highlevel judgment condemning the use of corporal punishment can

33 Civil Society Organisation including Save the Children and ANPPCAN Kenya formed a coalition campaigning for law reform to achieve full prohibition of corporal punishment of children. For example, from 2005, ANPPCAN Kenya organised the annual "No Kiboko Day", ("No beating Day") where children and other stakeholders engage in activities regarding non-violent forms of discipline.

34 Article 29 of the Constitution 2010 states that every person "has the right to freedom and security of the person, which includes the right not to be - ... (c) subjected to any form of violence from either public or private sources; (d) subjected to torture in any manner, whether physical or psychological; (e) subjected to corporal punishment; or (f) treated or punished in a cruel, inhuman or degrading manner." 
effectively protect children from all corporal punishment. ${ }^{35}$ In Bangladesh for instance, the Government reported to the Committee on the Rights of the Child in 2015, that a number of legislative measures were being developed, including a "Ban on Corporal Punishment Policy and Guideline". 36 Similarly in Tonga, a law reform process was initiated soon after the court judgment against judicial corporal punishment. ${ }^{37}$

Another aspect to note is that some of the concerned countries have since officially declared their intention to prohibit in all settings to international human rights mechanisms. The Governments of Bangladesh, India and Fiji accepted recommendations to prohibit corporal punishment made during their respective Universal Periodic Reviews. ${ }^{58}$ Italy for its part, has been consistently questioned about its intention to bring legislation into line with the 1996 Supreme Court ruling against corporal punishment by international human rights mechanisms. Based on this, it may be argued that even when national high-level judgments are not confirmed in legislation, they may still be used as a means of pressure at national and international levels, which increasingly promote children's human right to be protected against violence.

Strategic litigation can also foster civil society's pressure in promoting the human right imperative to prohibit corporal punishment of children. For instance, the above-mentioned court cases in Bangladesh, Canada, India and Nepal were filed by civil society organisations. Similarly, in 2003 and 2013, using the collective complaints procedure of the European Social Charter, on two separate occasions non-governmental organisations brought complaints against Italy on the grounds that it failed to take measures to prohibit corporal punishment of children in all settings. These examples show that in addition to promoting law reform and lobbying Governments and Members of Parliaments, civil society organisations can promote prohibition by challenging the legality of corporal punishment. In doing so, they may use national legal systems, as well as international and regional human rights instruments.

35 See Freedom of Religion South Africa $v$ Minister of Justice and Constitutional Development and Others (2019) CC, ZACC34; In this case, the South Africa Constitutional Court ruled that the common law defence of 'reasonable and moderate chastisement' was unconstitutional, effectively banning all corporal punishment of children since there was no similar defence in legislation,

3612 August 2015, CRC/C/BGD/Q/5/Add.1, Reply to list of issues, paras. 24 and 26

37 DCI Juvenile Justice Newsletter 2007, No. 3, 30 June 2007

38 For Bangladesh see 5 October 2009, A/HRC/11/18, Report of the working group, para. 94(16) and 25 May 2018, A/HRC/WG.6/30/L.10 Unedited version, Draft report of the working group, paras. 147(45), 147(52), 147(55), 147(56). For India see 17 September 2012, A/HRC/21/10/Add.1, Report of the working group: Addendum. For Fiji see 17 December 2014, A/ HRC/28/8, Report of the working group, para. 100(5) and 8 May 2017, A/ HRC/WG.6/27/L.8, Draft report of the working group, unedited version, paras. 5(233), 5(234) and 5(235). 
Judgments of high-level court cases can also trigger changes in the general perception of the protection and promotion of human rights. In Kenya, for example, as mentioned earlier, although the judge did not challenge the right of parents and others to administer "reasonable punishment" under article 127 of the Children's Act, it confirmed that judges had the power to examine the status of corporal punishment in the home. With this case, the judge found that parents' actions under the guise of "discipline" could constitute cruel, inhuman and degrading treatment and could be punished as such. The defence of "reasonable punishment" could no longer prevent judges' scrutiny. Equally, in Italy, even though the law provides for a right to correction, the judge was of the view that corporal punishment was obsolete and in breach with international human rights instruments. Finally, in Nepal, before the publication of the 2006 UN Secretary General's Study on Violence against Children which recommended prohibition and elimination of corporal punishment as a matter of priority, in its judgment in 2005, the Supreme court held that "there seems no reason for Nepal not to take an initiative in the universal campaign against physical punishment or torture”.

Strategic litigation is also evidence that increasingly, in their judgments, courts are referring to international human rights instruments, especially the Convention on the Rights of the Child and other human rights treaties - in addition to their national constitutions. In Bangladesh, Costa Rica, India, Israel and Italy, the courts explicitly quoted the Convention on the Rights of the Child - (articles 19, 28 and 37). In Bangladesh, the court even used the definition of corporal punishment adopted by the Committee on the Rights of the Child in its General Comment No. 8 on corporal punishment and other cruel or degrading forms of punishment. ${ }^{39}$ Likewise, in Costa Rica, the court referred to the recommendations made by the Committee to prohibit corporal punishment in the home. Overall, international and regional human rights instruments and treaty bodies documents seem to guide national high level courts decisions with a view to confirm children's status as rights holders. It should also be noted that in some cases, courts have paid particular attention to other countries' judgments on the issue of corporal punishment. For instance, in the judgment of Bangladesh in 2001, reference was made to the above-mentioned Delhi Supreme Court judgment on school corporal punishment. In Fiji also, the court quoted similar judgments in Namibia (Ex Parte Attorney General of Namibia: in re Corporal Punishment by Organs of State) and Zimbabwe (Ncube and Others $v$ State).

39 General Comment No. 8 (2006): The right of the child to protection from corporal punishment and other cruel or degrading forms of punishment (arts. 19; 28, para. 2, and 37, inter alia). 


\section{Conclusion}

High-level court judgments on the legal and constitutional status of corporal punishment have been published worldwide. A trend that is worth noting is that in some cases judgments condemning corporal punishment (clearly or not), have been precursors of law reform to prohibit corporal punishment in one or all settings (e.g. Costa Rica, Israel and Kenya). In other cases, countries have not confirmed the judgments in legislation, keeping corporal punishment lawful in some or all settings. Be that as it may, it seems that none of the judgments examined have been contradicted by subsequent national judgments. In fact, they are even quoted by other national courts interchangeably. The impact of high-level judgments on corporal punishment therefore cannot be underestimated. First of all, as seen in the above-mentioned South African example, ${ }^{40}$ it may lead to the effective ban of corporal punishment. Equally, when a high-level judgment condemning corporal punishment is not sufficient to achieve prohibition as in the selected countries of this chapter, it may still constitute an advocacy tool for civil society in its quest for achieving full prohibition in legislation. It is an important means of pressure for treaty bodies when they assess countries' performance in the protection of children from violence. In sum, the effectiveness of national judgments in achieving prohibition of corporal punishment should be considered in a wider context, in other words, judgments should be seen as a critical step leading to law reform. Governments, civil society and other stakeholders will still have a significant role to play with a view to ensure that the judgments are confirmed into legislation. Finally, it should also be noted that achieving law reform to prohibit corporal punishment is yet another step in the protection of children from violence. Indeed, sensitization campaigns and other educational measures will still need to be carried out to ensure elimination of corporal punishment of children.

40 Freedom of Religion South Africa v Minister of Justice and Constitutional Development and Others (2019) CC, ZACC 34. 